\title{
Analisis Marjin Harga, Keuntungan, dan Share Keuntungan Pemasaran Ayam Ras Pedaging (Broiler) di PT. Ciomas Adisatwa Kota Metro
}

\section{Analysis of Price, Profit, and Profit Sharing Margin for Broiler at PT. Ciomas Adisatwa Metro City}

\author{
Parel Heldi ${ }^{1}$, Asek $\mathrm{A}^{1}$, Herawati $\mathrm{M}^{1}$ \\ ${ }^{1}$ Fakultas Peternakan, Universitas Tulang Bawang Lampung, Jl. Gajah Mada, Bandar \\ Lampung \\ Pareheldil677@gmail.com
}

\begin{abstract}
The aim of this research is from this research to find out 1) what kind of marketing institution plays a role in the marketing of broiler chickens in the partnership of PT. Ciomas Adisatwa and 2) price margins, profits, and marketing profits for broiler broiler at PT. Ciomas Adisatwa Metro City. The research method used in the research is using quantitative descriptive method. The research sample is a partnership farmer of PT. Ciomas Adisatwa, traders, and end consumers who buy chicken sourced from partnership farmers. Data analysis techniques used are analysis of price margins, profits, and profit share. The results of the research are three channels of marketing broiler broiler in Metro City, namely the first channel consists of breeders, collectors I, collectors' II traders, collectors III, retailers and consumers. The second marketing channel is farmers, collectors I, collectors II, retailers, and consumers. The third marketing channel pattern is breeders, collectors, retailers, and consumers. The highest price margin is found in the pattern of the first third marketing channel, namely at the retail level, while the largest profit share is in the second channel pattern, that is, the collecting traders I.
\end{abstract}

Keywords: Broiler, Price, Profit, Share Profit Margins

\section{PENDAHULUAN}

Usaha peternakan unggas di Indonesia semakin berkembang, hal ini tercernin dari posisinya sebagai usaha yang handal, karena memberikan sumbangan terhadap peningkatan pendapatan, lapangan pekerjaan, pemenuhan kebutuhan gizi masyarakat dan penopang sektor industri. Pertumbuhan produksi ayam ras pedaging pada tahun 2005 - 2006 adalah sebesar 10,55 persen dan pada tahun 2006 - 2007 sebesar 6,64 persen. Kontribusi ayam ras pedaging terhadap produksi daging di Indonesia sejak tahun 2005 hingga 2007 selalu mendominasi. Produksi ayam ras pedaging pada tahun 2005 sebesar 44,5 persen dan tahun 2006 mencapai 43,5 persen, kemudian diikuti daging dari jenis sapi potong dan ayam buras. Produksi ayam ras pedaging yang cukup besar menggambarkan ketersediaan pasar dan pertumbuhan tingkat konsumsi terhadap komoditas tersebut. (Prasetyo, 2008).

Salah satu faktor pendukung berhasilnya suatu usaha petemakan ayam broiler tersebut adalah pemasaran yang dilaksanakan dengan baik. Menurut Gitosudarmo (1994) pemasaran dapat diartikan sebagai suatu kegiatan yang mengusahakan agar produk yang dipasarkan itu dapat diterima dan disenangi pasar. Suatu perusahaan besar dengan tingkat pemasaran yang telah meluas, tentunya membutuhkan suatu kemitraan 
dalam usahanya. Dengan membuat suatu jalinan kerjasama usaha yang merupakan strategi bisnis yang dilakukan antara dua pihak atau lebih dengan prinsip saling menguntungkan.

Kerjasama tersebut tersirat adanya satu pembinaan dan pengembangan. Hal ini dapat terlihat karena pada dasamya masing-masing pihak pasti mempunyai kelemahan dan kelebihan, sehingga akan saling melengkapi antara kedua belah pihak yang bekerja sama. Dalam hal ini, PT. Ciomas Adisatwa sebagai perusahan kemitraan ayam broiler, harus dapat menjaga kualitas dagingnya dengan selalu memperhatikan manajemen penanganan mulai dari pengadaan bibit hingga tersampainya produk kepada konsumen.

Keuntungan usaha ayam ras pedaging tidak terlepas dari harga pasar. Namun kenyatannya harga pasar yang tinggi tidak diiringi harga yang ditingkat tingkat peternak, dimana terdapat marjin harga yang masih terlalu tinggi. Selisih harga diberbagai saluran pemasaran masih tinggi. Berikut ini disajikan selisih harga ayam broiler di berbagai saluran pemasaran.

Tabel 1. Harga Ayam Broiler pada Berbagai Tingkat Saluran Pemasaran

\begin{tabular}{lrrr}
\hline Bulan & $\begin{array}{c}\text { Harga Kontrak } \\
\text { Peternak }\end{array}$ & $\begin{array}{c}\text { Harga Pedagang } \\
\text { Pengumpul }\end{array}$ & $\begin{array}{c}\text { Harga Pasar } \\
\text { (Rp) }\end{array}$ \\
\hline Januari & 15.500 & 16.800 & 21.000 \\
Februari & 15.500 & 14.500 & 20.500 \\
Maret & 15.250 & 14.900 & 20.500 \\
April & 15.300 & 16.500 & 21.500 \\
Mei & 16.200 & 18.350 & 23.000 \\
Juni & 15.250 & 17.200 & 22.000 \\
\hline
\end{tabular}

Sumber: data PT.Ciomas Adisatwa

Pada Tabel 1 di atas terlihat bahwa masih terjadi kesenjangan harga ditingkat petemak dan konsumen hal im menggambarkan marjin harga yang diterima petemak masih kecil. Tingginya marjin harga berupakan salah satu indikasi pemasaran ayam ras broiler belum efisien.

Berdasarkan latar belakang tersebut, maka rumusan masalah yang diambil adalah saluran pemasaran apa saja yang berperan dalam pemasaran ayam broiler di kemitraan PT. Ciomas Adisatwa. Bagaimana marjin dan share keuntungan yang diterima oleh peternak.

\section{METODOLOGI PENELITIAN}

\section{Tempat dan Waktu Penelitian}

Penelitian ini dilakukan di P.T. Ciomas Adisatwa Kota Metro pada Bulan Agustus 2017.

\section{Sampel Penelitian}

Sampel penelitian adalah peternak kemitraan PT. Ciomas Adisatwa, pedagang, dan konsumen akhir yang membeli ayam yang bersumber dari peternak kemitraan. Teknik pengambilan sampel yang digunakan adalah untuk peternak menggunakan metode purposive sampling sedangkan pedagang menggunakan metode snowball dengan sensus sampel jenuh 


\section{Metode Pengumpulan Data}

Metode pengumpulan data yang digunakan dengan observasi dan interview dengan menggunakan daftar pertanyaan (kuesioner).

\section{Analisis Data}

\section{Analisis Marjin Pemasaran}

$$
M P=P r-P f
$$

Keterangan:

$$
\begin{array}{ll}
\mathrm{MP} & =\text { Marjin PemasaranAyam Broiler } \\
\mathrm{Pr} & =\text { Harga di tingkat konsumen }(\mathrm{Rp} / \mathrm{Kg}) \\
\mathrm{Pf} & =\text { Harga di tingkat peternak }(\mathrm{Rp} / \mathrm{Kg})
\end{array}
$$

\section{Keuntungan}

Keuntungan yang diperoleh masing-masing lembaga pemasaran, digunakan rumus:

$$
\Pi=M-B p
$$

Keterangan:

$\Pi \quad=$ Keuntungan Lembaga Pemasaran

$\mathrm{M} \quad=$ Margin Pemasaran

$\mathrm{Bp} \quad=$ Biaya Penjualan

\section{Analisis Share Keuntungan}

$$
S k i=\frac{K p i}{P r-P f}-x 100 \%
$$

Keterangan:

Ski = Share keuntungan lembaga pemasaran (\%)

$\mathrm{Kpi}=$ Keuntungan lembaga pemasaran ke-i

$\mathrm{Pr} \quad=$ Harga ditingkat konsumen

$\mathrm{Pf} \quad=$ Harga ditingkat petemak

\section{HASIL PENELITIAN DAN PEMBAHASAN}

\section{Saluran Pemasaran Ayam Ras Broiler di Kota Metro}

Terdapat tiga pola pemasaran ayam ras pedaging di Kota Metro. Pola saluran pertama merupakan saluran pemasaran terpanjang yang meliputi peternak, pedagang pengumpul I, pedagang pengumpul II, pedagang pengumpul III, pengecer, dan konsumen. Pola saluran kedua dan merupakan terpanjang kedua yang meliputi peternak, pedagang pengumpul I, pedagang pengumpul II, pengecer, dan konsumen. Selanjutnya pola saluran ketiga yang merupakan pola saluran terpendek yaitu peternak, pedagang pengumpul I, pengecer, dan konsumen. 


\section{Analisis Marjin Harga}

Hasil analisis marjin harga pemasaran ayam ras pedaging di Kota Metro dapat dilihat pada Tabel 2.

Tabel 2. Hasil Analisis Marjin Harga pada Setiap Saluran Pemasaran

\begin{tabular}{ccccc}
\hline Pola Saluran & $\begin{array}{c}\text { Harga Peternak } \\
(\mathbf{R} \mathbf{p})\end{array}$ & $\begin{array}{c}\text { Harga } \\
\text { Konsumen (Rp) }\end{array}$ & $\begin{array}{c}\text { Marjin Harga } \\
(\mathbf{R p})\end{array}$ & $\%$ \\
\hline Pola 1 & $16.599,20$ & $30.600,00$ & $14.000,80$ & 54,25 \\
Pola 2 & $16.480,00$ & $30.400,00$ & $13.920,00$ & 54,21 \\
Pola 3 & $16.480,00$ & $28.800,00$ & $12.320,00$ & 57,22 \\
\hline
\end{tabular}

Berdasarkan Tabel 2 di atas teralihat bahwa harga terbesar pada pola pemasaran ketiga yaitu $57,25 \%$. Hal ini disebabkan pola pemasaran ketiga adalah pola pemasaran dengan rantai pemasaran terpendek.

\section{Analisis Keuntungan}

Hasil analisis keuntungan pemasaran ayam ras pedaging di Kota Metro dapat dilihat pada Tabel 3.

Tabel 3. Hasil Analisis Keuntungan pada Setiap Saluran Pemasaran

\begin{tabular}{|c|c|c|c|c|c|}
\hline Saluran & $\begin{array}{c}\text { Peternak } \\
\text { (Rp/kg) }\end{array}$ & $\mathrm{P} 1(\mathrm{Rp} / \mathrm{kg})$ & P2(Rp/kg) & $\begin{array}{c}\text { P3 } \\
(\mathrm{Rp} / \mathrm{kg})\end{array}$ & $\begin{array}{l}\text { Pengece } \\
\text { r (Rp/kg) }\end{array}$ \\
\hline Pola 1 & $1.296,20$ & 500,00 & $2.400,00$ & $5.559,00$ & $2.000,00$ \\
\hline Pola 2 & 941,00 & $1.500,00$ & - & $5.059,00$ & $3.000,00$ \\
\hline Pola 3 & 941,00 & - & - & $7.000,00$ & $2.493,56$ \\
\hline
\end{tabular}

Keterangan: $\mathrm{P} 1=$ Pedagang Pengumpul $\mathrm{I}, \mathrm{P} 2=$ Pedagang Pengumpul $\mathrm{II}, \mathrm{P} 3=$ Pedagang Pengumpul III

Berdasarkan Tabel 3 terlihat pada pola saluran pertama keuntungan terbesar diperoleh oleh pemotong dan keuntungan terkecil pada pedagang pengumpul 1. Pada seluran kedua keuntungan keuntungan terbesar diperoleh oleh pemotong dan keuntungan terkecil pada peternak. Selanjutnya pada pola saluran ketiga keuntungan terbesar pada pemotong dan terkecil adalah pada peternak. Berdasarkan data ini maka dapat disimpulkan keuntungan terbesar adalah pada pemotong untuk setiap saluran pemasaran.

\section{Analisis Share Keuntungan}

Hasil analisis share keuntungan pemasaran ayam ras pedaging di Kota Metro dapat dilihat pada Tabel 4.

Tabel 4. Hasil Share Analisis Keuntungan pada Setiap Saluran Pemasaran

\begin{tabular}{ccrrrrr}
\hline \multirow{2}{*}{ No } & \multirow{2}{*}{ Saluran } & Peternak & \multicolumn{4}{c}{ Share Keuntungan (\%) } \\
\cline { 4 - 7 } & & $(\mathrm{Rp} / \mathrm{kg})$ & \multicolumn{1}{c}{ P1 } & P2 & P3 & Pengecer \\
\hline 1 & Pola 1 & $1.296,20$ & $78,03 \%$ & $88,86 \%$ & $52,44 \%$ & $14,28 \%$ \\
2 & Pola 2 & 941,00 & $100,00 \%$ & - & $47,19 \%$ & $9,82 \%$ \\
3 & Pola 3 & 941,00 & - & - & $65,30 \%$ & $10,42 \%$ \\
\hline
\end{tabular}

Keterangan: P1 = Pedagang Pengumpul I, P2 = Pedagang Pengumpul II, P3 = Pedagang Pengumpul III 
Pada Tabel 4 terlihat bahwa share keuntungan pada saluran pertama diporoleh olah pedagang pengumpul 2, pada pola saluran kedua yaitu pada pedagang pengumpul 1 , sedangkan pada pola saluran ketiga share keuntungan terbesar pada pada pemotong.

\section{Pola Saluran Pemasaran}

Berdasarkan penelitian diperoleh secara umum terdapat tiga pola saluran yaiitu saluran pertama adalah saluran terpanjang yaitu 6 saluran dimual dari peternak, pedagang pengumpul I, pedagang pengumpul II, pedagang pengumpul III, pengecer, dan konsumen. Saluran yang panjang ini sudah tentu berdampak pada rendahnya marjin harga dan keuntungan yang diperoleh oleh peternak.

Saluran kedua terdiri dari 5 saluran yaitu peternak, pedagang pengumpul I, pengumpul II, pengecer, dan konsumen. Sedangkan saluran ketiga tediri dari 4 saluran pemasaran yaitu peternak, pedagang pengumpul I (pemotong), pengecer, dan konsumen.

Pada setiap pemasaran selalu terjadi fungsi pemasaran yaitu kegiatan untuk mempelancar penyampaian barang. Berikut ini disajikan dalam bentuk Tabel fungsi pemasaran ras pedaging di Kota Metro.

Tabel 5. Fungsi Pemasaran Ayam Broiler di Kota Metro

\begin{tabular}{cccccc}
\hline Fungsi Pemasaran & Peternak & $\begin{array}{c}\text { Pedagang } \\
\text { Pengumpul I }\end{array}$ & $\begin{array}{c}\text { Pedagang } \\
\text { Pengumpul } \\
\text { II }\end{array}$ & $\begin{array}{c}\text { Pedagang } \\
\text { Pengumpul } \\
\text { III }\end{array}$ & Pengecer \\
\hline Pertukaran & $\mathrm{M}$ & $\mathrm{M}$ & $\mathrm{M}$ & $\mathrm{M}$ & $\mathrm{M}$ \\
- Pembelian & $\mathrm{M}$ & $\mathrm{M}$ & $\mathrm{M}$ & $\mathrm{M}$ & $\mathrm{M}$ \\
- Penjualan & & $\mathrm{M}$ & $\mathrm{TM}$ & $\mathrm{M}$ & $\mathrm{TM}$ \\
Fisik & $\mathrm{MM}$ & $\mathrm{M}$ & $\mathrm{M}$ & $\mathrm{M}$ & $\mathrm{TM}$ \\
- Pemotongan & $\mathrm{M}$ & $\mathrm{M}$ & $\mathrm{M}$ & $\mathrm{M}$ & $\mathrm{M}$ \\
- Penyimpanan & $\mathrm{TM}$ & $\mathrm{M}$ & $\mathrm{TM}$ & $\mathrm{TM}$ \\
- Pengangkutan & $\mathrm{TM}$ & $\mathrm{TM}$ & $\mathrm{M}$ & $\mathrm{M}$ & $\mathrm{M}$ \\
- Pengolahan & $\mathrm{M}$ & $\mathrm{M}$ & $\mathrm{TM}$ & $\mathrm{M}$ & $\mathrm{M}$ \\
Fasilitas & $\mathrm{TM}$ & $\mathrm{M}$ & $\mathrm{M}$ & $\mathrm{M}$ & $\mathrm{M}$ \\
- Grading & $\mathrm{M}$ & $\mathrm{M}$ & $\mathrm{M}$ & $\mathrm{M}$ & \\
- Pembiayaan & $\mathrm{M}$ & $\mathrm{M}$ & & & \\
- Penanggungan & risiko & &
\end{tabular}

Keterangan: $\mathrm{M}=$ Melakukan, $\mathrm{TM}=$ Tidak melakukan

Pada Tabel 5 di atas terlhat fungsi pemasaran terbanyak dilakukan oleh pedagang pengumpul I, hanya fungsi pemisik bagian pengolahan yang tidak dilakukannya.

\section{a. Fungsi pertukaran}

Fungsi pertukaran menggambarkan terjadinya pemindahan kepemilikan yang disebabkan adanya transaksi.

1) Pedagang Pengumpul I

Pedagang pengumpul I melakukan pembelian ayam kepada peternak dalam jumlah yang cukup besar. Proses pembelian biasanya pedagang pengumpul I melalui transaksi dengan perusahaan inti. Hal ini disebabkan peternak hanya menerima harga kontrak dari perusahaan inti, sedangkan penjualan selanjutnya ditentukan oleh perusahaan inti

2) Pedagang Pengumpul II

Pedagang pengumpul II membeli ayam dari pengumpul I berbentuk ayam telah dipotong, karena pedagang pengumpul I juga berfungsi 
sebagai pemotong. Biasanya pedagang pengumpul II membeli ayam berdasarkan bobot.

3) Pedagang pengumpul III

Pedagang pengumpul III membeli ayam dari pengumpul II berbentuk ayam yang telah hidup dan pembelian berdasarkan bobot. Kemudian Pedagang pengumpul III melakukan pemotongan dan menjualnya pada pengecer.

4) Pengecer

Pedagang pengecer yang membeli ayam pada pedagang pengumpul II biasaya dalam bentuk ayam karkas dan dibayar secara tunai. Selanjutnya pengecer menjual dengan dua cara yaitu menjual di pasar dan menjual berdasarkan pesanan pelanggan (warung makan).

\section{b. Fungsi Fisik}

1) Pedagang Pengumpul I

Fungsi fisik yang dilakukan oleh pedagang pengumpul I adalah pemotongan, pengangkutan, penyimpanan, dan pengolahan. Pemotongan dilakukan oleh tenaga kerja yang disiapkan oleh pedagang pengumpul I. Setelah dipotong selanjutnya bulu ayam dibubuti dengan mesin pembubut bulu ayam. Selanjutnya proses yang dilakukan adalah pengangkuatan dengan menggunakan kendaraan roda empat (truk).

2) Pedagang Pengumpul II

Pedagang pengumpul melakukan fungsi fisik yaitu penyimpanan dan pengangkuatan Ayam yang diperoleh dari pedangang pengumpul I selanjutnya di simpan sebelum di distribusikan kepada pengecer.

3) Pengecer

Fungsi fisik yang dilakukan oleh pengecer adalah penyimpanan dan pengangkuatan. Ayam yang diperoleh dari pedagang pengumpul II biasanya penyimpanan terhadap ayam tidak terjual habis. Fungasi pengangkutan dilakukan pengecer yaitu mengangkut ayam dari pedagang pengumpul I ke pasar atau ke pelanggan (warung).

\section{c. Fungsi Fasilitas}

1) Pedagang Pengumpul I

Fungsi fasilitas yang dilakukan oleh pedagang besar adalah grading, pembiayaan, dan risiko. Fungsi grading dilakukan oleh pedagang pengumpul I yaitu dengan membeli ayam dari peternak berdasarkan ukuran tertentu. Fungsi pembiayaan yaitu biaya tranportasi, tenaga kerja, dan penyimpanan. Fungsi risiko adalah pedagang pengumpul menanggung risiko kematian dan pengurangan bobot badan saat pengangkutan.

2) Pedagang Pengumpul II

Pedagang pengumpul II melakukan fungsi pemasaran meliputi, pembiayaan dan risiko. Pembiayan pedagang pengumpul II meliputi pengangkutan, penyimpanan, dan tenaga kerja. Selanjutnya risiko yang diperoleh penurunan bobot badan.

3) Pengecer

Pengecer hanya melakukuan pembiayaan yaitu biaya yang dikeluarkan untuk pengangkutan dan tenaga kerja.

\section{Marjin Harga}

Analisis marjin harga pada Tabel 2 menunjukkan bahwa marjin harga tertinggi terdapat pada saluran pertama yaitu Rp14.000,80, kemudian pada pola saluran kedua yaitu Rp13.920, dan terakhir pada pola saluran ketiga dengan 
marjin harga Rp12.320,00. Pola saluran pertama merupakan pola saluran pemasaran terpanjang, dengan demikian semakin panjang saluran pemasaran semakin tinggi marjin harga ayam broiler. Hal ini sejalan dengan hasil penelitian Annisa, dkk (2015) yang menemukan semakin panjang rantai pemasaran semakin tinggi margin harga.

\section{Analisis Keuntungan}

Berdasarkan Tabel 3 terlihat bahwa pada pola saluran pertama keuntungan tebesar diperoleh oleh pemotong yaitu Rp5.5559,00 per $\mathrm{kg}$, sedangkan keuntungan terkecil diperoleh oleh pedagang pengumpul pertama yaitu Rp500 per $\mathrm{kg}$. Pada pola saluran kedua keuntungan terbesar juga diperoleh oleh pemotong yaitu 5.059,00, sedangkan keuntungan terendah diperoleh oleh peternak yaitu sebesar Rp941,00 per kg. Sama seperti pada saluran pertama dan kedua keuntungan terbesar diperoleh oleh pemotong yaitu $\mathrm{Rp} 7.000,00$ per $\mathrm{kg}$, sedangkan terendah diperoleh oleh peternak Rp941,00. Hasil penelitian menunjukkan bahwa peternak masih pihak yang dapat menerima keuntungan yang layak dari kegiatan pemasaran ayam broiler. Keuntungan terbesar masih diperoleh oleh pedagang pengumpul.

\section{Share Keuntungan}

Berdasarkan hasil analisis (Tabel 4) diperoleh share keuntungan tebesar diterima pada saluran pertama adalah pedagang pengumpul kedua $88,86 \%$, sedangkan terendah adalah pengecer sebesar $14,79 \%$. Pada pola saluran kedua share keuntungan terbsesar masih diterima oleh pedagang pengumpul pertama yaitu $100,00 \%$ dan terkecil terima pengecer yaitu $9,82 \%$. Selanjutnya pada pola saluran ketiga share tertinggi diterima oleh pemotong yaitu $65,03 \%$ dan terkecil pengecer $10,42 \%$. Hasil analisis ini menunjukkan bahwa pemotong adalah lembaga pemasaran yang memperoleh share keuntungan terbesar, sedangkan terkecil adalah pengecer.

\section{KESIMPULAN}

Terdapat tiga saluran pemasaran ayam ras broiler di Kota Metro yaitu saluran pertama terdiri dari peternak, pedagang pengumpul I, pedagang pengumpul II, pedagang pengumpul III, pengecer dan konsumen. Saluran pemasaran kedua adalah peternak, pedagang pengumpul I, pedagang pengumpul II, pengecer, dan konsumen. Pola saluran pemasaran ketiga adalah peternak, pedagang pengumpul I, pengecer, dan konsumen.

Margin harga tertinggi terdapat pada pola saluran pemasaran pertama ketiga yaitu pada tingkat pengecer. Keuntungan peteranak pola saluran pertama adalah Rp1.296,20/kg, pedagang pengumpul I (P1) Rp500,00/kg, pedagang pengumpul I (P2) Rp2.400,00/kg pedagang pengumpul III (P3) Rp5.559,00/kg dan pengecer Rp2.000,00/kg. Pada pola saluran kedua keuntungan peternak adalah Rp941,00/kg, pedagang pengumpul I (P1) Rp1.500,00/kg, pedagang pengumpul III Rp5.059,00/kg, dan pengecer Rp3.000,00/kg. Pada pola saluran ketiga peternak memperoleh Rp941,00/kg, pedagang pengumpul III (P3) $\mathrm{Rp} 7.000,00 / \mathrm{kg}$, dan pengecer Rp2.493,56.kg. Share keuntungan terbesar pada pola saluran kedua yaitu pada pedagang pengumpul $\mathrm{I}$.

\section{DAFTAR PUSTAKA}

Annisa, dkk. 2015. Analisis Pola Saluran Pemasaran Dan Marjin Serta Efisiensi Pemasaran Ayam Broiler Pada Sistem Kemitraan Di Kabupaten Grobogan. 
Animal Agriculture Journal 4(1): 144-148, April 2015

Badan Pusat Statistik Kota Metro. 2014. Kota metro dalam angka.

Gitosudarmo, H. 1994. Manajemen pemasaran. edisi pertama. BPFE. Yogyakarta.

Prasetyo, S. 2008. Pengaruh Harga KomoditasSubstitusi Dan Komplementer Terhadap Permintaan Daging Ayam Ras Di Kabupaten Bogor. (Skripsi). Fakultas Pertanian, Institut Pertanian Bogor. 